\title{
DETERMINASI KEPEMIMPINAN KEPALA SEKOLAH, BUDAYA ORGANISASI, ETOS KERJA GURU DAN MOTIVASI KERJA TERHADAP KINERJA GURU DI SMK PARIWISATA HARAPAN DENPASAR
}

\author{
I Gusti Ayu Monika, A.A. Gede Agung, Kadek Rihendra Dantes \\ Jurusan Administrasi Pendidikan \\ Universitas Pendidikan Ganesha \\ Singaraja, Indonesia \\ e-mail: \{ayumonika@gmail.com agungtps2056@gmail.com, \\ rihendra79@gmil.com\}
}

\begin{abstract}
Abstrak
Penelitian ini bertujuan untuk mengetahui determinasi kepemimpinan kepala sekolah, budaya organisasi, etos kerja guru, dan motivasi kerja terhadap kinerja guru di SMK Pariwisata Harapan Denpasar. Penelitian ini menggunakan desain "ex post facto". Populasi dan sampel penelitian ini adalah semua guru di SMK Pariwisata Harapan Denpasar, yang berjumlah 60 orang. Data dikumpulkan dengan kuesioner menggunakan skala Likert 1-5. Setelah data dikumpulkan, kemudian dianalisis menggunakan analisis regresi sederhana, korelasi parsial dan regresi berganda. Berdasarkan hasil analisis data, hasil penelitian menunjukkan bahwa (1) terdapat determinasi yang tidak signifikan kepemimpinan kepala sekolah terhadap kinerja guru dengan Sumbangan Efektif (SE) sebesar 1,86\%. (2) terdapat determinasi yang signifikan budaya organisasi terhadap kinerja guru dengan Sumbangan Efektif (SE) sebesar 11,31\%. (3) terdapat determinasi yang tidak signifikan etos kerja guru terhadap kinerja guru dengan Sumbangan Efektif (SE) sebesar 2,50\%. (4) terdapat determinasi yang tidak signifikan motivasi kerja dan kinerja guru dengan Sumbangan Efektif (SE) sebesar 1,49\%,(5) secara bersama-sama terdapat determinasi yang signifikan kepemimpinan kepala sekolah, budaya organisasi, etos kerja guru dan motivasi kerja terhadap kinerja guru dengan determinasi $17,20 \%$. Berdasarkan temuan tersebut dapat disimpulkan bahwa terdapat determinasi yang positf dan signifikan dari budaya organisasi terhadap kinerja guru di SMK Pariwisata Harapan Denpasar. Budaya organisasi yang terbentuk memberikan determinasi yang paling besar. Hal ini berarti budaya organisasi merupakan prediktor yang paling dominan dalam meningkatkan kinerja guru di SMK Pariwisata Harapan Denpasar.
\end{abstract}

Kata kunci: kepemimpinan, budaya organisasi, etos kerja guru, motivasi kerja dan kinerja guru

\begin{abstract}
This study aims to analyze the determination of principal leadership, organizational culture, teacher work ethic, and work motivation on teacher performance in SMK Pariwisata Harapan Vacational High School in Denpasar. The research utilized "ex post facto" design. The population and sample for the study consist of all 60 teachers at SMK Pariwisata Harapan Denpasar. The data was collected through questionnaire using the Likert scale (1 to 5). Following the data collection, the data was analyzed using simple regression, partial correlation, and multiple correlation. Based on the data analysis, the results of the research that (1) there is an insignificant determination between principal leadership and teacher performance with Effective Contribution of $1.86 \%$; (2) there is a significant determination between organizational culture and teacher performance with Effective Contribution of $11.31 \%$; (3) there is an insignificant determination between teacher work ethic and teacher performance with Effective Contribution of 2.50\%; (4) there is an insignificant determination between work motivation and teacher performance with Effective Contribution of $1.49 \%$; and (5) simultaneously there is a significant determination between principal leadership, organizational culture, teacher work
\end{abstract}


ethic, and work motivation on teacher performance with determination value of $17.20 \%$. Based on these findings it can be concluded that there is a positive and significant determination of organizational culture and teacher performance in SMK Pariwisata Harapan Vacational High School in Denpasar. The formed organizational culture provides the greatest determination. This means that organizational culture is the most dominant predictor in improving teacher performance in SMK Pariwisata Harapan Vacational High School in Denpasar.

Keywords : principal leadership, organizational culture, techer work ethic, work motivation, teacher performance

\section{PENDAHULUAN}

Permasalahan yang paling krusial yang dihadapi bangsa ini antara lain menyangkut pemberdayaan sumber daya manusia yang mencapai jumlah 250 juta jiwa dengan pertumbuhan penduduk sebesar 1,49 persen per tahun; pertumbuhan angkatan kerja lebih besar dari pada ketersediaan lapangan pekerjaan; distribusi penduduk antar daerah kurang merata; ketidaksesuaian kompetensi SDM dengan pasar kerja; ketidak seimbangan kebutuhan layanan publik; distribusi informasi tentang pasar kerja yang lambat atau timpang; permintaan tenaga kerja yang belum terpetakan dengan baik; tingginya tingkat pengangguran dan kemiskinan secar simultan menyebabkan rendahnya kualitas pendidikan dan kesehatan, dan pada akhirnya menyebabkan rendahnya kualitas SDM di Indonesia.

Programme for International Study Assessement (PISA) pada tahun 2012 menempatkan Indonesia sebagai salah satu negara dengan peringkat terendah dalam pencapaian mutu pendidikan. Pemeringkatan tersebut dapat dilihat dari skor yang dicapai pelajar usia 15 tahun dalam kemampuan membaca, metematika dan sains. Dalam studi yang dilakukan oleh PISA, mutu pendidikan Indonesia yang rendah dikonfirmasikan dengan anggaran dan biaya pendidikan yang langsung dibayar masyarakat naik signifikan dari tahun ke tahun. PISA merupakan studi internasional yang diselenggarakan Organization for Economic Cooperation and Development (OECD) Priansa (2014:5).

Pendidikan merupakan sarana yang paling penting dalam mengembangkan sumber daya manusia (SDM) dan watak bangsa (Nation Character Building). Harkat dan martabat suatu bangsa sangat ditentukan oleh mutu pendidikannya. Dalam konteks bangsa Indonesia, peningkatan mutu pendidikan merupakan sasaran pembangunan di bidang pendidikan nasional dan merupakan bagian integral dari upaya peningkatan kualitas manusia Indonesia secara menyeluruh Mulyasa (2005:125).

Mengingat begitu pentingnya peran pendidikan bagi kehidupan masyarakat, maka dewasa ini pemerintah berupaya untuk meningkatkan kualitas pendidikan, termasuk peningkatan mutu produktivitas guru. Harapan agar pendidikan di Indonesia bangkit dari keterpurukan dan menjadi garda terdepan dalam pembangunan bangsa. Bentuk perhatian ini secara khusus tercermin dalam kebijakan pemerintah, antara lain: berupa pemenuhan sarana Perundang-Undangan, peningkatan anggaran pendidikan, sampai pada upaya penyempurnaan berbagai regulasi yang berlaku untuk memajukan pendidikan nasional.

Hal tersebut merupakan sebuah upaya yang dilandasi adanya kesadaran untuk mewujudkan amanat konstitusi yang diletakkan para founding father negara ini, yaitu dalam Pasal 31 ayat (2) Undang-Undang dasar 1945 mengisyaratkan bahwa: "Setiap warga negara wajib mengikuti pendidikan dasar dan pemerintah wajib membiayainya". Dan Pasal 31 ayat (3) yang menyatakan, bahwa: "Pemerintah mengusahakan dan menyelenggarakan satu sistem pendidikan nasional, yang meningkatkan keimanan dan ketaqwaan serta akhlak mulia dalam rangka mencerdaskan kehidupan bangsa, yang diatur dengan UndangUndang".

Sebagai upaya melaksanakan amanat kontitusi itulah, pada saat ini pemerintah pusat maupun daerah berkonsentrasi secara penuh terhadap kemajuan dalam pembangunan pendidikan, dalam rangka meningkatkan SDM yang diyakini sebagai faktor penunjang akselerator kemajuan. Peningkatan SDM melalui bidang pendidikan dapat dicapai, jika guru yang berfungsi sebagai pendidik memiliki kualitas yang tinggi. 
Pembagunan pendidikan bertumpu pada empat pilar kebijakan strategis Departemen Pendidikan Nasional, yaitu: (1) Availability atau ketersediaan;(2) Affordability atau keterjangkauan;(3) Quality atau kualitas pendidikan;(4) Assurance atau penjamainan mutu pendidikan. Hasil kajian dan evaluasi tersebut harus dikomunikasikan kepada semua pihak yang terkait. Inilah bentuk akuntabilitas yang sesungguhnya yang harus dilakukan oleh semua pihak, dan itulah satu bentuk jaminan mutu pendidikan yang harus dipertanggungjawabkan secara transparan kepada publik.

Tujuan pendidikan tersebut tidak akan dapat terwujud, tanpa didukung oleh brainware yang memadai, secanggih apapun peralatan serta dana yang melimpah yang tersedia tidak akan mampu memberikan manfaat secara fungsional sebagaimana mestinya. Sesempurna apapun perencanaan visi dan misi suatu organisasi dan tanpa didukung dengan adanya sumber daya manusia yang berkualitas memiliki kepribadian dan motivasi yang tinggi maka kemungkinan pencapaian tujuan dari organisasi mengalami kegagalan. Oleh sebab itu organisasi sekolah harus mampu menyatukan persepsi atau cara pandang guru, staf serta kepala sekolah dalam pencapaian tujuan antara lain melalui pembentukan mental kerja yang baik dengan dedikasi serta loyalitas yang tinggi terhadap pekerjaannya, memberikan motivasi kerja, bimbingan, pengarahan, dan koordinasi yang baik dalam bekerja untuk mentransformasi perubahan.

Berbagai upaya yang dilakukan pemerintah untuk meningkatkan kualitas pendidikan belum menunjukkan hasil yang menggembirakan, bahkan masih banyak kegagalan dalam implementasinya dilapangan. Kegagalan demi kegagalan antara lain disebabkan oleh masalah manajemen yang kurang tepat, penempatan tenaga tidak sesuai dengan bidang keahlian, dan penanganan masalah bukan oleh ahlinya, sehingga tujuan pendidikan nasional untuk mencerdaskan kehidupan bangsa melalui peningkatan mutu pada setiap jenis dan jenjang pendidikan belum dapat diwujudkan, (Mulyasa, 2013:6).

Mutu pendidikan menjadi pembicaraan dalam kalangan masyarakat. Hal ini disebabkan karena masyarakat merasa sangat khawatir terhadap masa depan generasi muda yang tampaknya kurang serius dalam menjalani pendidikan di sekolah, hal ini disebabkan oleh beberapa faktor salah satunya adalah kemampuan guru dalam mengoptimalkan potensi yang di miliki oleh siswanya. Pendidikan dalam masa era globalisasi merupakan pendidikan yang akan menjawab tantangan masa depan secara global, dimana pendidikan akan dapat melahirkan individu yang memiliki bekal pengetahuan, keterampilan, serta nilai-nilai yang diperlukan untuk berkembang dalam era globalisasi.

Undang-Undang No. 20 Tahun 2003 tentang Sistem Pendidikan Nasional pada pasal 39 ayat 2 menyatakan bahwa tugas guru adalah merencanakan dan melaksanakan proses pembelajaran, menilai hasil pembelajaran, melakukan pembimbingan, dan pelatihan. Selanjutnya Undang-Undang No.14 tahun 2005 tentang Guru dan Dosen pada pasal 1 ayat 1 menyatakan bahwa guru adalah pendidik profesional dengan tugas utama mendidik, mengajar, membimbing, mengarahkan, melatih, menilai dan mengevaluasi peserta didik pada pendidikan anak usia dini jalur pendidikan formal, pendidikan dasar, dan pendidikan menengah. Selanjutnya pasal 20 menyatakan bahwa salah satu kewajiban profesional guru adalah merencanakan pembelajaran, melaksanakan proses pembelajaran yang bermutu, menilai dan mengevaluasi hasil pembelajaran, serta meningkatkan dan mengembangkan kualifikasi akademik dan kompetensi secara berkelanjutan sejalan dengan perkembangan ilmu pengetahuan, teknologi dan seni.

Peraturan Pemerintah No. 74 Tahun 2008 tentang Guru pada Pasal 52 ayat 1 menegaskan bahwa tugas pokok guru, yaitu merencanakan pembelajaran, melaksanakan pembelajaran, menilai hasil pembelajaran, membimbing dan melatih peserta didik, dan melaksanakan tugas tambahan yang melekat pada pelaksanaan kegiatan pokok sesuai dengan beban kerja guru.

Berbagai tugas yang diemban oleh guru seperti diamanatkan oleh berbagai peraturan tersebut menyiratkan betapa strategisnya tugas guru dalam mengembangkan berbagai potensi yang dimiliki oleh peserta didik. Guru tidak hanya menjadi rujukan utama peserta didik dalam melaksanakan proses pembelajaran di kelas, tetapi lebih dari itu guru adalah sebagai "pencipta" penting, peran dan perilaku peserta didik sangat dinamis. Seorang guru 
tidak cukup hanya profesional, memiliki kompetensi yang memadai, namun juga terus mampu mengembangkan dirinya sesuai dengan perubahan jaman dan menjadi bagian penting dalam masyarakat.

Dalam kegiatan pendidikan di sekolah, guru merupakan salah satu komponen dalam proses kegiatan belajar mengajar, yang berperan aktif dalam usaha pembentukan sumber daya manusia yang memiliki potensi dibidang pembangunan. Oleh sebab itu guru merupakan salah satu unsur dalam bidang kependidikan berperan secara aktif untuk menempatkan posisinya sebagai tenaga profesional sesuai dengan tuntutan dari masyarakat yang semakin maju. Dalam hal ini dapat diartikan bahwa seorang guru tidak hanya berperan sebagai tenaga pengajar yang melaksanakan proses transfer ilmu kepada peserta didik, tetapi sekaligus sebagai pendidik yang melakukan proses transfer nilai-nilai dan sekaligus sebagai pembimbing yang memberikan pengarahan serta menuntun siswa dalam pembelajaran

Pengertian guru dalam konteks pendidikan terkait dengan profesi yang diembannya sebagai pendidik dan pengajar bagi peserta didik yang ada di berbagai jenjang pendidikan. Secara umum, baik dalam pekerjaan ataupun sebagai profesi, guru selalu disebut sebagai salah satu komponen utama pendidikan yang sangat penting. Guru, peserta didik, dan kurikulum merupakan tiga komponen utama yang menjadi tombak dalam sistem pendidikan nasional. Ketiga komponen pendidikan tersebut merupakan "conditio sine quanon" atau syarat mutlak dalam pendidikan sekolah.

Melalui guru, peserta didik dapat memperoleh transfer pengetahuan dan pemahaman yang dibutuhkan untuk pengembangan dirinya. Guru merupakan fasilitator utama di sekolah yang berfungsi untuk menggali, mengembangkan, dan mengoptimalkan potensi yang dimiliki oleh peserta didik sehingga ia bisa menjadi bagian dari masyarakat yang beradab. Berbagai peran ganda yang diemban guru bagi pengembangan peserta didik merupakan tugas mulia keprofesiannya, sekaligus sebagai komitmennya untuk mengembangkan pendidikan menjadi lebih baik dan berkualitas lagi, dalam rangka membangun masyarakat serta bangsa dan negara yang lebih beradab dan maju.

Jumlah tenaga pengajar serta kualitas dari guru akan mempengaruhi keberhasilan siswa dalam belajar, yang berujung pada peningkatan mutu pendidikan. Untuk itulah guru dituntut untuk lebih profesional dalam mengemban tugasnya. Guru sebagai pelaku utama untuk dapat merealisasikan program operasional pendidikan dan guru menjadi tumpuan harapan untuk dapat mewujudkan agenda-agenda pendidikan nasional seperti peningkatan mutu dan relevansi, pemerataan dan perluasan kesempatan belajar, dan peningkatan efisiensi. Hak-hak asasi guru sebagai pribadi, pemangku profesi keguruan, anggota masyarakat, dan warga negara perlu mendapat prioritas dalam pemberdayaannya. Upaya pembenahan kurikulum, perbaikan sarana, penyesuaian peraturan, manajemen dan lain sebagainya, tetapi tanpa guru yang bermutu, semua itu tidak ada artinya. Kurikulum yang kurang efektif dan sarana yang kurang maksimal, masih akan menghasilkan pendidikan yang baik apabila didukung oleh guru yang memiliki kualitas dan kinerja yang memadai.

Tugas keprofesionalan guru menurut Undang-Undang Republik Indonesia No. 14 Tahun 2005 pasal 20 (a) tentang Guru dan Dosen adalah merencanakan pembelajaran, melaksanakan proses pembelajaran yang bermutu, serta menilai dan mengevaluasi hasil pembelajaran. Tugas-tugas pokok guru tersebut diwujudkan dalam kegiatan proses belajar mengajar, dan tugas-tugas guru dalam kelembagaan merupakan bentuk wujud dari kinerja guru. Apabila kinerja guru semakin meningkat maka akan berpengaruh terhadap peningkatan kualitas outputnya, oleh sebab itu perlu mendapatkan dukungan dari berbagai pihak sekolah untuk dapat meningkatkan kinerja guru.

Kinerja guru yang tinggi salah satunya dapat ditunjukkan dengan profesionalisme guru yang terdiri atas penguasaan kompetensi. Kompetensi yang harus dikuasai meliputi kompetensi profesional, kompetensi pedagogis, kompetensi kepribadian dan kompetensi sosial. Oleh sebab itu kinerja memegang peranan yang sangat penting dalam pencapaian tujuan pengajaran agar tercapai dengan maksimal. Kenyataan yang terjadi dalam dunia pendidikan, permasalahan yang dihadapi yaitu masih ada guru yang mengajar tidak sesuai 
dengan bidangnya, sehingga untuk dapat menguasai kompetensi profesional dirasakan masih kurang.

Kinerja guru merupakan kinerja atau unjuk kerja yang dijalankan oleh guru dalam melaksanakan tugasnya sebagai pendidik. Kualitas kinerja guru akan sangat menentukan pada kualitas hasil pendidikan, karena guru yang berhadapan langsung dengan siswa dalam proses pendidikan atau pembelajaran. Guru sebagai tenaga pendidik merupakan pemimpin pendidikan, menetukan dalam proses pembelajaran di kelas, dan peran kepemimpinan tersebut akan tercermin dari bagaimana guru melaksanakan peran dan tugasnya, ini berarti bahwa kinerja guru merupakan faktor yang amat menentukan bagi mutu pembelajaran atau pendidikan yang akan berimplikasi pada kualitas output pendidikan setelah menyelesaikan di sekolah. Sehubungan dengan hal di atas, perlu dilakukan perbaikan dalam upaya meningkatkan kinerja guru di sekolah. Salah satunya dengan mengkaji berbagai faktor yang dimungkinkan mempengaruhi kinerja guru di sekolah.

Hal yang menjadi bahan pertimbangan adalah bagaimana kinerja guru berdampak terhadap pendidikan bermutu. Pertama adalah faktor kepemimpinan kepala sekolah, dalam sistem penyelenggaraan pendidikan ditingkat sekolah, kepala sekolah memiliki peranan yang strategis dalam memberdayakan guru-gurunya dalam upaya peningkatan mutu pendidikan.

Keberhasilan pendidikan di sekolah ditentukan juga oleh keberhasilan kepala sekolah dalam mengelola tenaga kependidikan yang ada dilingkungan sekolah. Kepala sekolah juga merupakan komponen pendidikan yang berpengaruh dalam meningkatkan kinerja guru. Kepala sekolah bertanggung jawab penuh dalam hal penyelenggaraan kegiatan pendidikan, administrasi sekolah, pembinaan tenaga kependidikan lainnya serta pendayagunaan pemeliharaan sarana dan prasarana (Mulyasa, 2004:25). Hal tersebut akan menjadi lebih penting sejalan dengan jelasnya tuntutan tugas kepala sekolah yang menghendaki dukungan kinerja yang efektif dan efisien.

Kepemimpinan kepala sekolah sangat berpengaruh dan menentukan kemajuan sekolah haruslah memiliki kemampuan administrasi, komitmen yang tinggi serta luwes dalam melaksanakan tugas dan perannya sebagai kepala sekolah. Kepemimpinan kepala sekolah yang baik harus dapat mengupayakan peningkatan kinerja guru melalui program-program pembinaan kemampuan tenaga kependidikan. Oleh sebab itu kepala sekolah haruslah memiliki kepribadian, sifat-sfat, kemampuan, serta keterampilan untuk dapat memimpin suatu lembaga pendidikan. Dalam menjalankan peranannya sebagai kepala sekolah harus dapat memperhatikan keperluan serta perasaan individu-individu yang diajak bekerja sehingga kinerja guru semakin meningkat dan dapat terjaga.

Tatang (2015:2-5) pemimpin pendidikan harus memiliki integrasi keterampilan teknis, pedagogis, profesional dan manajerial, yang juga disebut sebagai professional-asadministrator yang mencakup kualitas peran sebagai pimpinan eksekutif (chief executive) dan memimpin secara profesional (leading professional), dalam aspek internal maupun eksternal.

Faktor lain yang mempengaruhi kinerja guru adalah budaya organisasi sekolah yang juga dikenal dengan istilah iklim organisasi sekolah. Budaya organisasi sekolah menggambarkan suasana serta hubungan kerja antara guru dengan siswa, guru dengan sesama guru, antara guru dengan kepala sekolah, dan antara guru dengan tenaga kependidikan lainnya serta dinas dilingkungannya yang merupakan wujud lingkungan kerja kondusif.

Organisasi dibangun dengan tujuan mencapai tujuan tertentu oleh pendirinya. Budaya organisasi variasinya beragam bila dilihat dari sumber daya manusianya, dari segi umur, ras, suku, gender, tingkat pendidikan, pengalaman, serta latar belakang budayanya. Konflik akan dapat terjadi apabila keberagaman tidak teratasi dengan baik.

Pastin, (dalam Sutrisno, 2010:11) Budaya organisasi yang kuat meletakkan kepercayaan-kepercayaan, tingkah laku dan cara melakukan sesuatu, tanpa perlu dipertanyakan lagi. Oleh karena itu berakar dalam tradisi, budaya mencerminkan apa yang dilakukan, dan apa yang akan berlaku. Keberagaman yang dimaksudkan sangat dapat dirasakan, karena lembaga tempat bekerja berasal dari berbagai ras, suku, agama, dan 
bangsa. Hal itulah yang melatar belakangi mengapa budaya organisasi digunakan sebagai salah satu variabel dalam penelitian ini. Budaya organisasi merupakan salah satu variabel bebas dalam penelitian ini.

Faktor lain yang berpengaruh terhadap kinerja guru adalah etos kerja. Etos kerja dipandang memiliki keterkaitan terhadap kinerja guru. Anoraga (dalam Priansa 2016:282) menyatakan bahwa etos kerja merupakan suatu pandangan dan sikap suatu bangsa atau umat terhadap kerja. Pada intinya etos kerja adalah suatu sikap kerja guru terhadap kerja yang dicirikan dengan adanya bekerja tulus dengan penuh syukur, bekerja benar dengan penuh tanggung jawab, bekerja tuntas dengan penuh integritas, bekerja keras dengan penuh semangat, bekerja serius dengan penuh kecintaan, bekerja kreatif dengan penuh sukacita, bekerja tekun penuh dengan keunggulan, bekerja sempurna penuh dengan kerendahan hati. Etos kerja menjadi satu bagian penting untuk dapat mewujudkan kinerja yang baik. Etos kerja merupakan semangat kerja yang menjadi ciri khas dan keyakinan seseorang atau suatu kelompok. Guru yang memiliki etos kerja tinggi senantiasa berusaha agar tanggung jawab yang dipercayakan dapat dilaksanakan dengan baik.

Selain faktor-faktor di atas, faktor yang dianggap berpengaruh terhadap kinerja guru adalah motivasi. Fakor-faktor yang dapat menentukan kinerja seseorang sangatlah komplek, namun abilitas dan motivasi adalah sebagai faktor-faktor yang berinteraksi dengan kinerja. Abilitas seseorang ditentukan oleh skill serta pengetahuan, skill dapat dipengaruhi oleh kecakapan. Kepribadian serta pengetahuan dipengaruhi oleh pendidikan, pengalaman, latihan serta minat. Motivasi pada dasarnya bersumber pada diri seseorang yang dikenal sebagai motivasi internal serta dapat bersumber dari luar diri seseorang yang dikenal dngan motivasi eksternal. Faktor motivasi dapat berdampak positif maupun negatif terhadap kinerja seorag guru.

Dalam menjalankan tugas sebagai pendidik, guru memiliki sifat serta perilaku yang berbeda, ada yang bersemangat dan penuh tanggung jawab, ada juga guru yang menjalankan profesinya tanpa dilandasi dengan rasa tanggung jawab, selain itu ada juga guru yang sering membolos atau lebih suka memberikan tugas dan tidak masuk ke kelas, datang tidak tepat waktu serta tidak mentaati tata tertib yang berlaku. Kondisi guru seperti inilah yang menjadi permasalahan dalam lembaga pendidikan formal. Dengan demikian dapat dikatakan bahwa dengan adanya guru yang memiliki kinerja yang rendah sekolah akan sulit untuk mencapai hasil yang diharapkan.

Kedudukan guru sebagai tenaga profesional mempunyai visi terwujudnya penyelenggaraan pembelajaran sesuai dengan prinsip profesionalisme untuk memenuhi hak yang sama bagi setiap warga negara dalam memperoleh pendidikan yang bermutu. Kedudukan guru sebagai agen pembelajaran berkaitan dengan peran guru dalam pembelajaran, antara lain sebagai fasilitator, motivator, pemacu, perekayasa pembelajaran, dan pemberi inspirasi belajar bagi peserta didik. Peran tersebut menuntut guru untuk mampu meningkatkan kinerja dan profesionalismenya seiring dengan perubahan dan tuntutan yang muncul terhadap dunia pendidikan dewasa ini.

Peraturan Pemerintah Republik Indonesia Nomor 32 tahun 2013 tentang perubahan atas peraturan pemerintah nomor 19 tahun 2005 disebutkan bahwa (a) Standar Nasional Pendidikan perlu diselaraskan dengan dinamika perkembangan masyarakat, lokal, nasional, dan global guna mewujudkan fungsi dan tujuan pendidikan nasional. (b) Dalam rangka mencerdaskan kehidupan bangsa diperlukan komitmen nasional untuk meningkatkan mutu dan daya saing bangsa melalui pengaturan kembali Standar Kompetensi Lulusan, Standar Isi, Standar Proses, dan Standar Penilaian, serta pengaturan kembali Kurikulum.

Guru profesional yang dibuktikan dengan kompetensi yang dimilikinya akan mendorong terwujudnya proses dan bentuk kinerja yang dapat menunjang peningkatan kualitas pendidikan. Guru yang kompeten dapat dibuktikan dengan perolehan sertifikasi guru berikut tunjangan profesi yang memadai menurut standar hidup masyarakat berkecukupan.

Supriadi (dalam Werang, 2011:6) menegaskan bahwa seorang guru yang profesional harus memiliki hal berikut: (a) komitmen kepada siswa dan proses pembelajaran; (b) menguasai secara mendalam materi yang diajarkan kepada siswa; (c) bertanggung jawab membantu hasil belajar siswa melalui teknis evaluasi, baik pengamatan perilaku siswa 
maupun tes hasil belajar; (d) berpikir secara sistematis apa yang dilakukan dan selalu mau belajar dari pengalaman; dan (e) menjadi bagian dari masyarakat belajar dalam lingkungan profesinya.

Kualitas guru sangat identik dengan kinerja guru. Menurut Hasibuan (2007:3) kinerja guru atau prestasi kerja adalah suatu hasil kerja yang dicapai seseorang dalam melaksanakan tugas-tugas yang dibebankan kepadanya yang didasarkan atas kecakapan, pengalaman, dan kesungguhan serta waktu. Kinerja guru dikatakan baik jika guru telah melaksanakan unsur-unsur diantaranya kesetiaan dan komitmen tinggi pada tugas mengajar, menguasai dan mengembangkan bahan pengajaran, kerja sama dengan warga sekolah, kepemimpinan yang menjadi teladan siswa, kepribadian yang baik serta, jujur dan objektif dalam membimbing siswa, serta bertanggung jawab terhadap peranannya.

Berhasilnya pendidikan khususnya di sekolah ditentukan juga oleh keberhasilan kepala sekolah didalam mengelola tenaga kependidikan yang ada di sekolah. Kepala sekolah merupakan salah satu komponen pendidikan yang sangat berpengaruh terhadap peningkatan kinerja guru. Kepala sekolah bertanggung jawab terhadap penyelenggaraan pendidikan, administrasi sekolah, pembinaan tenaga kependidikan lainnya, dan pendayagunaan serta pemeliharaan sarana dan prasarana (Mulyasa, 2004:25).

Berdasarkan hasil dari wawancara dengan Kepala Sekolah di SMK Pariwisata Harapan yang beralamatkan di Jalan Raya Sesetan No 62 Sesetan, Denpasar Selatan, Kota Denpasar 80223 secara umum sudah berjalan dengan baik. Ketaatan guru dalam mengajar dan mentaati tata tertib yang berlaku juga sudah baik. Hal tersebut ditunjang oleh tata tertib sekolah dimana guru wajib mengisi daftar hadir pada pagi hari sebelum bekerja dan sore hari setelah selesai proses belajar mengajar. Dengan demikian kedisiplinan guru dalam bekerja dapat terpantau.

Dari uraian di atas dapat dipahami terdapat beberapa sisi menarik yang perlu dikaji lebih mendalam yaitu mengenai kinerja guru. Banyak faktor yang dapat mempengaruhi kinerja guru untuk dapat bekerja sesuai tuntutan tugasnya di sekolah. Dari fenomena yang terdapat dilapangan, tidak dapat dipungkiri masih terdapat beberapa kesenjangan antara harapan dengan kenyataan. Dalam kesempatan ini peneliti merasa perlu untuk mengkaji kinerja guru di SMK Pariwisata Harapan Denpasar dengan judul: Determinasi Kepemimpinan Kepala Sekolah, Budaya Organisasi, Etos Kerja Guru, dan Motivasi Kerja Terhadap Kinerja Guru di SMK Pariwisata Harapan Denpasar.

Berdasarkan latar belakang dan identifikasi masalah yang ada, maka permasalahannya dapat dirumuskan sebagai berikut.

1. Apakah terdapat determinasi yang signifikan kepemimpinan kepala sekolah terhadap kinerja guru di SMK Pariwisata Harapan Denpasar?

2. Apakah terdapat determinasi yang signifikan budaya organisasi terhadap kinerja guru di SMK Pariwisata Harapan Denpasar?

3. Apakah terdapat determinasi signifikan etos kerja guru terhadap kinerja guru di SMK Pariwisata Harapan Denpasar?

4. Apakah terdapat determinasi yang signifikan motivasi kerja terhadap kinerja guru di SMK Pariwisata Harapan Denpasar?

5. Apakah terdapat determinasi yang signifikan secara bersama-sama kepemimpinana kepala sekolah, budaya organisasi, etos kerja guru, dan motivasi kerja terhadap kinerja guru di SMK Pariwisata Harapan Denpasar?

Berdasarkan rumusan masalah yang dikemukakan di atas, maka penelitian ini bertujuan untuk:

1. Untuk mengetahui determinasi yang signifikan kepemimpinan kepala sekolah terhadap kinerja guru.

2. Untuk mengetahui determinasi yang signifikan budaya organisasi terhadap kinerja guru.

3. Untuk mengetahui determinasi yang signifikan etos kerja guru terhadap kinerja guru.

4. Untuk mengetahui determinasi yang signifikan motivasi kerja terhadap kinerja guru.

5. Untuk mengetahui bersama-sama determinasi yang signifikan kepemimpinan kepala sekolah, budaya organisasi, etos kerja guru, motivasi kerja terhadap kinerja guru. 


\section{METODE}

Penelitian ini menggunakan pendekatan ex post facto, yaitu penelitian yang bertujuan untuk menyelidiki peristiwa yang telah terjadi dan kemudian meruntut kebelakang untuk mengetahui faktor-faktor yang menyebabkan terjadinya peristiwa tersebut Sugiyono (2017:7). Pada penelitian ini pengumpulan analisis data yang diperoleh untuk mengungkapkan peristiwa yang terjadi. Hal ini disebabkan karena mengambil data yang sudah ada secara empiris tanpa melakukan eksperimen terhadap variabel. Dalam penelitian ini, ketika peneliti mengadakan pengamatan terhadap variabel terikat, variabel-variabel bebasnya sudah terjadi, Darmadi, (2011:223). Dengan kata lain, peneliti tidak akan memberikan perlakuan terhadap subjek atau sampel penelitian.

Populasi dan sampel penelitian ini adalah semua guru di SMK Pariwisata Harapan Denpasar, yang berjumlah 60 orang. Data dikumpulkan dengan kuesioner menggunakan skala Likert 1-5. Setelah data dikumpulkan, kemudian dianalisis menggunakan analisis regresi sederhana, korelasi parsial dan regresi berganda.

Variabel bebas $(X)$ dalam penelitian ini terdiri dari Kepemimpinan Kepala Sekolah $\left(X_{1}\right)$, Budaya Organisasi $\left(X_{2}\right)$, Etos Kerja Guru $\left(X_{3}\right)$, dan Motivasi Kerja $\left(X_{4}\right)$. Sedangkan variabel terikat $(Y)$ dalam penelitian ini adalah Kinerja Guru di SMK Pariwista Harapan Denpasar.

\section{HASIL DAN PEMBAHASAN}

Berdasarkan hasil temuan penelitian seperti yang telah dipaparkan didepan, berikut disajikan pembahasannya sebagai berikut

Tabel.1

Rangkuman Analisis Regresi dan Regresi Ganda Varibel Terikat Terhadap Variabel Bebas

\begin{tabular}{|c|c|c|c|c|c|c|c|c|c|}
\hline Variabel & $\begin{array}{c}\text { Persamaan } \\
\text { garis regresi }\end{array}$ & $r_{x y}$ & $r_{\text {parsial }}$ & $r_{\text {tabel }}$ & $\mathrm{R}_{\mathrm{y}}$ & $R y^{2}$ & F hit & $\begin{array}{l}\text { SE } \\
(\%)\end{array}$ & Ket \\
\hline$X_{1}-Y$ & $\begin{array}{l}\hat{Y}=121,741+ \\
0,262 . X_{1}\end{array}$ & 0,174 & 0,108 & 0,254 & - & - & - & 1,86 & Sig \\
\hline$X_{2}-Y$ & $\begin{array}{l}\hat{Y}=101,738+ \\
0,330 . X_{2}\end{array}$ & 0,363 & 0,286 & 0,254 & - & - & - & 11,31 & Sig \\
\hline$X_{3}-Y$ & $\begin{array}{l}\hat{Y}=116,499+ \\
0,292 \cdot X_{3}\end{array}$ & 0,248 & 0,098 & 0,254 & - & - & - & 2,50 & Sig \\
\hline$X_{4}-Y$ & $\begin{array}{l}\hat{Y}=129,777+ \\
0,162 X_{4}\end{array}$ & 0,153 & 0,153 & 0,254 & - & - & - & 1,49 & Sig \\
\hline $\begin{array}{l}X_{1} X_{2} X_{3} X_{4} \\
-Y\end{array}$ & $\begin{array}{l}\hat{Y}=59,626+ \\
0,162 . \\
X_{1}+0,276 \cdot X_{2} \\
+0,119 . X_{3}+ \\
0,104 . X_{4}\end{array}$ & - & - & - & 0,415 & 0,172 & 2,858 & - & Sig \\
\hline
\end{tabular}

Hasil analisis ditemukan:(1) terdapat determinasi yang tidak signifikan kepemimpinan kepala sekolah terhadap kinerja guru di SMK Pariwisata Harapan Denpasar melalui persamaan garis regresi $\hat{y}=121,741+0,262$. $X_{1}$ dengan sumbangan efektif (SE) sebesar $1,86 \%$, (2) terdapat determinasi yang signifikan budaya organisasi terhadap kinerja guru di SMK Pariwisata Harapan Denpasar melalui persamaan garis regresi $\hat{y}=101,741+0,330 . X_{2}$ dengan sumbangan efektif (SE) sebesar $11,31 \%$, (3) terdapat determinasi yang tidak signifikan etos kerja guru terhadap kinerja guru di SMK Pariwisata Harapan Denpasar melalui persamaan garis regresi $\hat{y}=116,499+0,292 . X_{3}$ dengan sumbangan efektif (SE) sebesar 2,50\%, (4) terdapat determinasi yang tidak signifikan motivasi kerja terhadap kinerja guru di SMK Pariwisata Harapan Denpasar melalui persamaan garis regresi $\hat{y}=$ $129,777+0,162$. $\mathrm{X}_{4}$ dengan sumbangan efektif (SE) sebesar 1,49\%, (5) terdapat determinasi yang signifikan secara bersama-sama kepemimpinan kepala sekolah,budaya organisasi, etos kerja guru dan motivasi kerja terhadap kinerja guru di SMK Pariwisata Harapan 
Denpasar melalui persamaan garis regresi $\hat{y}=59,626+0,162 . X_{1}+0,276 X_{2}+0,119 X_{3}+$ $0,104 \mathrm{X}_{4}$ dengan determinasi sebesar $17,20 \%$ dalam artian sekitar $17,20 \%$ variasi dalam variabel kepemimpinan kepala sekolah, budaya organisasi, etos kerja guru dan motivasi kerja sedangkan sisanya ditentukan oleh variabel lain yang tidak diteliti.

\section{SIMPULAN DAN SARAN}

Berdasarkan hasil penelitian yang telah dipaparkan pada bab sebelumnya, maka dapat disimpulkan sebagai berikut.

1. Terdapat determinasi yang tidak signifikan kepemimpinan kepala sekolah terhadap kinerja guru di SMK Pariwisata Harapan Denpasar, melalui persamaan garis regresi $\hat{y}=121,741$ $+0,262$. $X_{1}$ dengan Sumbangan Efektif (SE) sebesar 1,86\%.

2. Terdapat determinasi yang signifikan budaya organisasi terhadap kinerja guru di SMK Pariwisata Harapan Denpasar, melalui persamaan garis regresi $\hat{y}=101,741+0,330 . X_{2}$ dengan Sumbangan Efektif (SE) sebesar 11,31\%.

3. Terdapat determinasi yang tidak signifikan etos kerja guru terhadap kinerja guru di SMK Pariwisata Harapan Denpasar, melalui persamaan garis regresi $\hat{y}=116,499+0,292 . X_{3}$ dengan Sumbangan Efektif (SE) sebesar 2,50\%.

4. Terdapat determinasi yang tidak signifikan motivasi kerja terhadap kinerja guru di SMK Pariwisata Harapan Denpasar, melalui persamaan garis regresi $\hat{y}=129,777+0,162 . X_{4}$ dengan Sumbangan Efektif (SE) sebesar 1,49\%.

5. Terdapat determinasi yang signifikan secara bersama-sama kepemimpinan kepala sekolah, budaya organisasi, etos kerja guru dan motivasi kerja terhadap kinerja guru di SMK Pariwisata Harapan Denpasar, melalui persamaan garis regresi $\hat{y}=59,626+$ $0,162 . X 1+0,276$ X2 + 0,119 X3 + 0,104 X4 dengan kontribusi sebesar 17,20\%.

Berdasarkan hasil temuan tersebut dapat disimpulkan bahwa terdapat determinasi yang signifikan kepemimpinan kepala sekolah, budaya organisasi, etos kerja guru dan motivasi kerja terhdap kinerja guru di SMK Pariwisata Harapan Denpasar secara terpisah maupun simultan. Dengan demikian keempat faktor tersebut dapat dijadikan prediktor kecenderungan kinerja guru di SMK Pariwisata Harapan Denpasar.

Berdasarkan temuan tersebut dapat disarankan beberapa hal sebagai berikut.

1. Kepada guru disarankan agar dapat meningkatkan dan mempertahankan budaya organisasinya. Dalam penelitian ini terbukti bahwa budaya organisasi memberikan determinasi yang signifikan terhadap kinerja guru. Guru sangat diharapkan untuk selalu dapat meningkatkan dan mempertahankan budaya organisasi sehingga guru tersebut dapat menunjukkan kinerja guru yang baik.

2. Kepada kepala sekolah, disarankan agar selalu dapat menjaga dan meningkatkan budaya organisasi sekolah. Dalam penelitian ini terbukti bahwa budaya organisasi memberikan determinasi yang signifikan terhadap kinerja guru. Sehingga kepala sekolah sebaiknya selalu dapat menjadi teladan dalam menerapkan dan menanam hal-hal yang berkenaan dengan budaya organisasi sehingga sekolah akan menjadi nyaman serta kondusif.

3. Kepada peneliti lain, disarankan agar penelitian ini dapat dijadikan suatu pijakan untuk melakukan penelitian lebih lanjut, terutama bagi yang ingin mengungkapkan kepemimpinan kepala sekolah, budaya organisasi, etos kerja guru, dan motivasi kerja terhadap kinerja guru di SMK Pariwisata Harapan Denpasar.

\section{DAFTAR PUSTAKA}

Agung, A.A.G. 2011. Menjadi Guru Profesional yang Tersertifikasi. Singaraja.

Darmadi. 2011. Metode Penelitian Pendidikan. Bandung: Alfabeta.

Hasibuan, M. S. P. 2007. Manajemen Sumber Daya Manusia. Jakarta: Bumi Aksara.

Mulyasa. 2004. Manajemen Berbasis Sekolah, Konsep Strategi dan Implementasi. Bandung: PT. Remaja Rosdakarya.

Mulyasa. 2005. Menjadi Guru Profesional. Bandung: PT. Remaja Rosda Karya 
Mulyasa. 2013. Menjadi Kepala Sekolah Profesional. Bandung: Remaja Rosdakarya.

Peraturan Pemerintah No. 74 tahun 2008. Tentang Guru.

Peraturan Pemerintah Republik Indonesia Nomor 32 Tahun 2013 tentang perubahan Standar Nasional Pendidikan.

Priansa, D J. 2014. Kinerja dan Profesionalisme Guru. Bandung: Alfabeta.

Priansa, D J.2016. Perencanaan dan Pengembangan SDM. Bandung: Alfabeta.

Sugiyono, 2017. Metode Penelitian Kuantitatif, Kualitatif dan R \& D. Bandung. Alfabeta.

Sutrisno, E. 2010. Budaya Organisasi, Jakarta: Kencana.

Tatang S. 2015. Manajemen Pendidikan Berbasis Sekolah. Bandung: Pustaka Setia.

Undang-Undang No. 14 Tahun 2005. tentang Guru dan Dosen.

Undang-Undang No. 20 tahun 2003. tentang Sistem Pendidikan Nasional.

Undang-Undang Dasar Negara Republik Indonesia tahun 1945

Werang. B.R. 2011. Faktor-faktor PenentuKualitas Guru. Malang: Elang Mas. 